\title{
Anti-B-Cell Therapies in Autoimmune Neurological Diseases: Rationale and Efficacy Trials
}

\author{
Harry Alexopoulos $^{1} \cdot$ Angie Biba $^{1} \cdot$ Marinos C. Dalakas ${ }^{2}$
}

Published online: 13 November 2015

(C) The American Society for Experimental NeuroTherapeutics, Inc. 2015

\begin{abstract}
B cells have an ever-increasing role in the etiopathology of a number of autoimmune neurological disorders, acting as antibody-producing cells and, most importantly, as sensors, coordinators, and regulators of the immune response. B cells, among other functions, regulate the T-cell activation process through their participation in antigen presentation and production of cytokines. The availability of monoclonal antibodies or fusion proteins against B-cell surface molecules or Bcell trophic factors bestows a rational approach for treating autoimmune neurological disorders, even when $\mathrm{T}$ cells are the main effector cells. This review summarizes basic aspects of $\mathrm{B}$-cell biology, discusses the role(s) of $\mathrm{B}$ cells in neurological autoimmunity, and presents anti-B-cell drugs that are either currently on the market or are expected to be available in the near future for treating neurological autoimmune disorders.
\end{abstract}

Key Words B cells $\cdot$ autoimmunity $\cdot$ neurological disorders · autoantibodies $\cdot$ rituximab $\cdot$ monoclonal antibodies.

Marinos C. Dalakas

mdalakas@med.uoa.gr

1 Neuroimmunology Unit, Department of Pathophysiology, Faculty of Medicine, National and Kapodistrian University of Athens, Athens, Greece

2 Department of Neurology, Thomas Jefferson University, Philadelphia, PA, USA

\section{Introduction}

Autoimmunity is the nonphysiological state in which immune components not only recognize self, otherwise an important physiological process, but also exert their actions against self. Similarly to systemic autoimmune diseases, autoimmune neurological diseases may be mediated by all elements of the immune system, including B cells. Traditionally, most of the work on autoimmune neurological disorders has been centered on the role of T-cell subtypes because the best studied neuroimmunological disorder, multiple sclerosis (MS) and its experimental model experimental allergic encephalomyelitis (EAE), are predominately mediated by effector T cells; this is also the case for its peripheral counterpart experimental allergic neuritis. In the last few years, however, these views have changed and the role of B cells, not only as antibodyproducing cells, but also as sensors, coordinators, and regulators of the immune response has strongly emerged generating significant clinical and research interest. B cells seem to play a fundamental role in the pathogenesis not only of demyelinating diseases, but also in other autoimmune central nervous system (CNS) and PNS diseases like encephalopathies, peripheral neuropathies, neuromuscular junction disorders, and muscle diseases. A major relevant development in the field has been the availability of new biological agents targeting $\mathrm{B}$ cells or B-cell pathways, highlighting the role of B-cell autoimmunity in the pathophysiology of neurological disorders and offering exciting new therapeutic interventions.

This paper provides an overview of B-cell biology; addresses the role of $\mathrm{B}$ cells in autoimmune neurological disorders, discusses the available anti-B-cell agents for the treatment of autoimmune neurological disorders, and highlights the promising new drugs currently in the offing. 


\section{Principles of B-Cell Development and Maturation}

\section{Early Antigen-Independent B-Cell Development}

In humans, following birth, the majority of B lymphocytes develop from hematopoietic stem cells in the bone marrow. There, during the first 2 stages of B-cell development, they obtain their antibody specificity by sequential rearrangement of the immunoglobulin heavy and light chains in an antigenindependent manner [1]. At the end of the first stage, pro-B cells, defined by the productive rearrangement and cellsurface expression of the $\mu \mathrm{Ig}$ heavy chain, enter into the pre$B$ cell stage, where rearrangement of the Ig light chain occurs. Once functional IgM molecules are expressed in the pre-Bcell surface, these cells exit the bone marrow and migrate into the spleen where they finalize their development by differentiating from immature $B$ cells to naïve mature follicular or marginal-zone B cells [2].

\section{Mature B-Cell Development: Follicular B Cells}

Mature but still naïve follicular cells (also called recirculating B cells), express both IgM and IgD isotypes and have the ability to recirculate through the follicles of secondary lymphoid organs in search of their cognate antigen. Once they encounter their antigen, the antigen is endocytosed and processed into linear peptides before being displayed on the cell surface by major histocompatibility complex II molecules [3].

At this stage, B cells migrate to extrafollicular spaces and interact with helper T cells (Th cells) that have been previously activated by antigen-presenting dendritic cells. There, Th cells activate further B cells with high antigen affinity, via CD40L, to produce plasmablasts and short-lived plasma cells $[4,5]$. These cells produce antibodies that contribute to the formation of immune complexes taken up by follicular dendritic cells which then produce chemokines and attract activated B cells back to the follicular space to initiate germinal center formation. Previously activated Th cells differentiate further under B-cell influence to follicular Th cells (Tfh cells) and also migrate towards germinal centers. At this time point, the duration of interaction between Tfh cells and B cells at the B-cell/T-cell zone border determines the fate of the activated B cells; if it is long enough, they differentiate into germinal center B cells, otherwise, they enter into the germinal center-independent memory B-cell pool [6].

\section{Memory B Cells: Long-lived Plasma Cells and Plasmablasts}

A number of events, highly relevant to autoimmunity, including affinity maturation, isotype switching, and generation of B memory cells and long-lived plasma cells, take place after a vigorous clonal expansion of activated $\mathrm{B}$ cells and germinal center creation at lymphoid follicles. In proliferating germinal centers, B-cell affinity maturation through somatic hypermutation of the $\operatorname{IgV}$ genes results in the development of B cells with increased antigen affinity. Some of these affinity-matured germinal center B cells terminally differentiate into short-lived, circulating antigen-producing plasmablasts or long-lived quiescent plasma cells that migrate back to the bone marrow and maintain long-term antibody production [7]. Another fate for affinity-matured germinal center B cells is to exit germinal centers as memory B cells [6]. These antigen-experienced $B$ cells express high-affinity antibodies and have the ability to differentiate quickly into plasma cells upon future antigen encounters.

Long-lived memory B cells are able to mount a quick and efficient production of antibodies upon repeated exposure to their relevant antigen [6]. The involvement of memory B cells in a number of autoimmune disorders has been highlighted by the aberrant repopulation of memory B cells after B-cell depletion in rheumatoid arthritis (RA) and systemic lupus erythematosus (SLE) [8-11]. Of relevance to anti-B-cell therapy is the recent observation that activated $\mathrm{CD} 95+$ memory $\mathrm{B}$ cells were found to be increased in the peripheral blood of patients with RA while lower numbers at depletion time points correlated with good clinical response to B-cell depletion therapy [12].

\section{B-Cell Markers at Various Stages of Maturation}

Specific markers identify the transitional phases of B cells from stem cells to plasma cells. Typically, CD19 is expressed from the pre-B-cell stage to the late plasmablast stage, while CD20 is expressed after the pre-B-cell stage. Other important markers are $\mathrm{CD} 27$, which is present in the memory, late plasmablast, and plasma cell stages, and the B-cell activating factor (BAFF) receptor, which is present in the memory and late plasma blast stages. Finally, CD138 is expressed only on plasma cells (see Table 1). As we will discuss later, these markers are very important for the development of B-cellspecific and stage-specific therapies. Memory B cells, plasmablasts, and long-lived plasma cells may migrate also to the brain, prompted by specific cytokines, such as CXCL10, CXCL12, and CXCL13, secreted from the endothelial cell wall.

\section{B-Cell Trophic Factors: BAFF, A ProlifeRation Inducing Ligand, and Their Receptors}

BAFF [of the tumor necrosis factor (TNF) family; also known as BLyS, TALL1, and TNFSF13B] has been identified as a factor essential for B-cell survival and maturation along with the B-cell receptor (BCR) [13, 14]. A ProlifeRation Inducing Ligand (APRIL) also known as TALL2 and TNFSF13A, is also a member of the TNF family that shares only $30 \%$ 


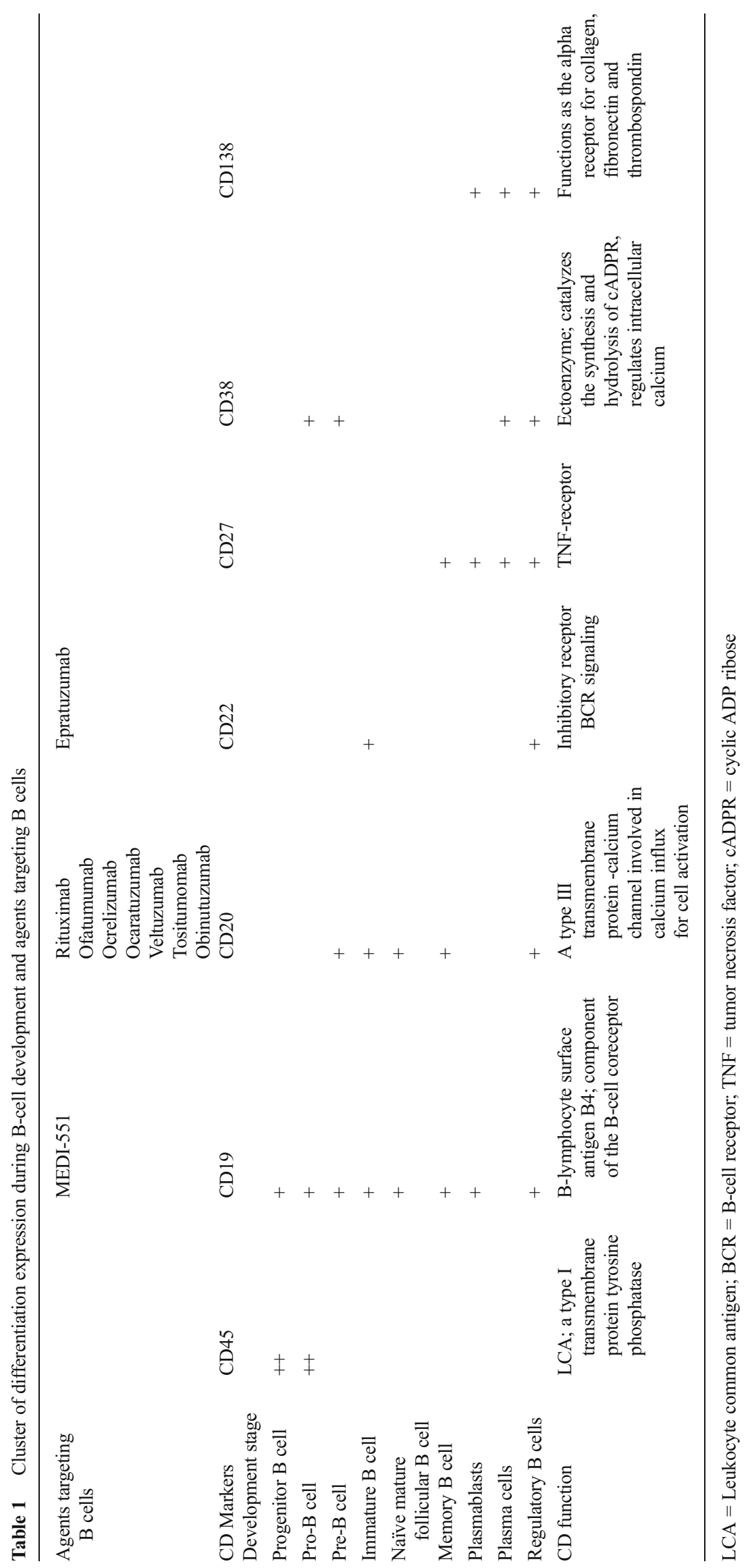


homology with BAFF but has similar functions [15]. BAFF and APRIL are both type II transmembrane proteins cleaved by a furin protease to produce their soluble forms. BAFF is expressed as a membrane-bound monomer or is cleaved to produce active BAFF trimmers [16, 17]. Active APRIL, however, is secreted following intracellular processing in the Golgi apparatus and is found only in its soluble form [18]. In humans, major sources of BAFF and APRIL are neutrophils and monocytes (macrophages and dendritic cells) and activated T cells [19-21].

BAFF binds strongly to the BAFF receptor (also known as TNFRSF13C), transmembrane activator and cyclophilin ligand interactor (TACI) (also known as TNFRSF13B), Nogo-66 receptor (also known as RTN4R), and weakly to B-cell maturation antigen (BCMA; also known as TNFRSF17) [22-24]. In contrast, APRIL binds strongly to BCMA and moderately to TACI, with which it interacts to also bind heparin sulfate proteoglycans [23, 25]. BAFF-R expression is absent during the early stages of the B-cell lineage; its expression coincides with functional $\mathrm{BCR}$ expression by immature $\mathrm{B}$ cells in the bone marrow and is essential for $\mathrm{B}$ cell survival and maturation [13, 14, 26, 27]. TACI is mainly expressed on memory B cells and BCMA on plasmablasts and plasma cells [28-30]. A number of these molecules are therapeutic targets, as discussed later.

\section{Regulatory B Cells and B-Cell-Related Cytokines}

In the last decade, an additional role of $\mathrm{B}$ cells as a negative regulator of autoimmune responses has emerged [31]. Unlike T regulatory cells, B regulatory cells (Bregs) are not, at least as yet, characterized by the expression of a lineage-specific transcription factor, like FOXP3, but rather by their ability to produce a variety of anti-inflammatory signals within an inflammatory environment [32]. The most common way they exert their regulatory function is by the production of interleukin (IL)-10 production [33]. In healthy populations, the B cells responsible for anti-inflammatory cytokine production (IL-10 and IL-35) are mostly naïve Bregs and regulatory plasma Bregs; in contrast, memory B cells produce largely proinflammatory cytokines, like lymphotoxin and TNF- $\alpha$, suggesting a dysfunction in IL-10 production in autoimmunity [34, 35]. Another subset of Bregs in humans is the B10 cells, which are activated by LPS and suppress TNF- $\alpha$ production via IL10 expression [36].

\section{B Cells, B-Cell Trophic Factors, Memory B Cells, and Bregs in Neurological Autoimmune Disorders: Rationale for Anti-B-Cell Therapy}

As already alluded to, the modern view for the role of B cells in the immune response implicates them in antigen presentation, antibody secretion, and optimal regulation of T-cell activation [37]. In autoimmunity, probably the most important effector action of $\mathrm{B}$ cells is the production of autoantibodies by plasma cells that have evaded the self-tolerance check points [38]. Although in some neurological diseases autoantibodies are directly pathogenic [i.e., antiacetylcholine receptor (AChR) in myasthenia gravis (MG), antimyelin-associated glycoprotein (MAG) in IgM paraproteinemic neuropathy, anti- $N$-methyl-D-aspartate receptor (NMDAR) in limbic encephalitis, antiaquaporin 4 (AQP4) in neuromyelitis optica (NMO)], in most others autoantibodies [like those seen in paraneoplastic neuropathies, multifocal motor neuropathy, or stiff person syndrome (SPS)] do not exert a direct effect on self-antigens and may only be disease markers. In these cases, it is the antibodyindependent functions of B cells, including antigen presentation, co-stimulation, cytokine production, and coordination of T-cell functions that implicate B cells in their pathogenesis [39].

\section{MS and NMO}

B cells are very important for MS pathogenesis, even though their role is not yet fully elucidated. In lesions of acute and relapsing MS, B cells and plasma cells are rare [40], although their numbers increase as the disease progresses [41]. These plasma cells produce immunoglobulin within the lesion and intrathecally. This intrathecal production of antibodies is detectable in the cerebrospinal fluid (CSF) and is of diagnostic value (oligoclonal bands) [42]. Once migrated into the brain, like in several documented cases of secondary progressive MS, activated B cells form germinal centers, even within intermeningeal spaces, where they follow the same differentiation pathways, as if they were in the periphery. From within these structures, B cells can stimulate plasma cells for additional in situ production of IgG. Similar structures may also be responsible for the intrathecal IgG production in other diseases where high titers of self-reactive antibodies are detected in the CSF, for example in NMDAR encephaliltis.

Earlier studies in MS have also revealed the presence of CD27+ IgD- memory B cells in the CSF of patients supporting the clonal expansion of B cells within the CNS [43]. In the peripheral blood, however, B-cell subsets, including memory B cells, are not numerically or phenotypically different than healthy controls $[44,45]$.

Bregs also play a role in NMO and MS [46-49]. Toll-like receptor 9-mediated IL-10 production by Bregs from patients with MS is significantly reduced compared with controls, owing to decreased Toll-like receptor 9 expression in memory B cells [50]. Even more pronounced is the reduction of IL-10 in patients with NMO, especially in anti-AQP4 seronegative NMO [49]. The ratio of naïve/memory IL-10-producing Bregs (B10 cells) is decreased in patients with MS during relapses 
compared with healthy controls [47]. In patients with NMO the memory/regulatory B cell ratio was found to be reduced because of a reduction in memory $\mathrm{B}$ cells following rituximab treatment (a B-cell-depleting monoclonal antibody), while Bregs were spared [51].

In EAE, B cells are also involved in the initiation of the inflammatory lesions within the CNS with reduced disease activity after B-cell depletion and reduction of anti-IgM antibodies [52, 53]. While B-cell depletion before EAE initiation hugely exacerbates disease symptoms, mainly because of a lack of B10 cells, B-cell depletion with anti-CD20 antibody dramatically suppresses EAE. The importance of B10 cells also suppress the initiation of EAE by significantly reducing the production of interferon- $\gamma$ and TNF- $\alpha$ by antigen-specific CD4+ T cells. In addition, IL-10 produced by B10 cells reduces antigen presentation by dendritic cells and the subsequent activation of CD4+ T cells [54].

Another important recent development is the re-emergence of anti-myelin oligodendrocyte glycoprotein (MOG) antibodies as markers and possible pathogenetic factors in central demyelination. MOG-derived peptides are the most common immunizing antigens in EAE, and MOG has long been considered as an autoantigen in MS. With advances in diagnostic methods it was shown that these antibodies are not present in patients with relapsing-remitting MS (RRMS) or primary progressive MS but they are mostly present in pediatric patients with MS, in patients with acute disseminating encephalomyelitis, and in patients with relapsing optic neuritis [55-57].

Finally, the BAFF/APRIL system is also involved. Although serum BAFF levels appear normal in patients with MS, involvement of the BAFF/APRIL system is supported by increased levels in the CSF of patients with MS [58], and the expression of BAFF in MS lesions is probably produced by astrocytes that support B-cell survival in situ [59]. Expression of BAFF/ APRIL receptors is not altered in MS sera but increased levels of BCMA have been observed in MS lesions [60].

In NMO, a recent string of studies show that the repopulation of peripheral blood by B cells, especially memory B cells, coincides with clinical relapses [51, 61-63]. Compared with healthy controls, patients with NMO have higher serum BAFF levels, which further increases after rituximab treatment [62]. Although CSF APRIL was not only increased in patients with NMO, it was also associated with disease disability [58]. The recent discovery that BAFF is a functional ligand of Nogo-66 receptor, which inhibits axonal growth and is overexpressed by astrocytes in MS lesions, could potentially provide at least 1 of the missing links between immune responses and degeneration in CNS diseases such as MS and NMO [24, 64].

\section{Autoimmune Polyneuropathies}

In polyneuropathies including Guillain-Barré syndrome (GBS), chronic inflammatory demyelinating polyneuropathy
(CIDP), and IgM anti-MAG antibody demyelinating neuropathy (anti-MAG neuropathy), B-cell involvement is supported by a string of data. Different antiganglioside antibodies are associated with GBS subtypes and some of them may be pathogenic as they can induce conduction block and acute neuropathy [65-68]. Overall, IgG antibodies that react with GM1, GD1a, GalNAc-GD1a, and GM1b are found in $80 \%$ of patients with axonal GBS (acute motor axonal neuropathy and acute motor and sensory axonal neuropathy), while antiGQ1b antibodies are detected in $>90 \%$ of patients with the Miller-Fisher variant [65-67].

In contrast to GBS, however, no single antibody has yet been identified as the primary causative factor in CIDP, despite the compelling indirect evidence provided by the rapid beneficial effect of plasmapheresis $[65,69]$. The first indication that antibodies are involved in CIDP was the presence of complement-fixing IgG and IgM deposits on a patient's myelin sheath [70], while the presence of a band, probably $\operatorname{IgG}$, in their CSF provided further credence [71]. Recently, albeit in small number of patients, several autoantibodies have been identified mainly targeting the paranodal sections of the nodes of Ranvier [72]. The action of these antibodies against molecules such as neurofascin 155 , contactin-associated protein 1 , and contactin-1, which are necessary for maintaining nodal structure, may explain the reversal of conduction block observed following effective therapies such as plasmapheresis or intravenous immunoglobulin (IVIG). Further, B cells from patients with CIDP exhibit reduced expression of Fc $\gamma$ RIIB, an inhibitory receptor that prevents $\mathrm{B}$ cells from entering the germinal centers to become IgG-positive plasma cells [73]. This observation, if confirmed, may further support the role of B cells in the disease. Serum levels of BAFF are decreased in CIDP presumably because of the presence of anti-BAFF antibodies in the IVIG preparations used for treatment [74].

Regarding MAG/sulfoglucuronyl paraglobosideassociated neuropathy, strong evidence suggests that the antibodies are causative because 1) IgM and complement are deposited in myelinated fibers in patients' sural nerve biopsies [75]; 2) the patients' IgM recognizes the neural cell adhesion molecule and co-localizes with MAG on the areas of the split myelin, implicating a myelin disadhesion process induced by the circulating anti-MAG IgM [76]; 3) in skin biopsies from patients, there is deposition of IgM, complement, and MAG on the intradermal myelinated fibers with a concurrent loss of nerve fibers, suggesting IgM-induced fiber loss [76]; and 4) corroborative data from animal models, either from intraneural injections into peripheral nerve or from immunization with sulfoglucuronyl paragloboside.

Patients with anti-MAG neuropathy treated with rituximab saw clinical benefit, reduction of anti-IgM and anti-MAG antibodies, and upregulation of Tregs [77, 78]. Further, patients with anti-MAG neuropathy show substantial clonal expansions of IgM memory B cells that recognized MAG antigen, 
while patients who experience clinical improvement after rituximab have lower numbers of anti-MAG memory B cells before and after therapy, and lower somatic hypermutation frequencies of IgM memory B cells [79].

\section{SPS and Autoimmune Encephalopathies}

Immune neurological diseases for which B-cell depletion therapies are used off-label, include SPS and autoimmune encephalopathies, including NMDAR encephalitis and progressive encephalomyelitis with rigidity and myoclonus. Increased B cell and anti-GAD65 IgG + memory B cell numbers have been reported in SPS [80], and the hallmark of the disease is the presence of autoreactive anti-GAD, antiamphiphysin or antiglycine receptor antibodies $[81,82]$.

\section{MG}

In MG, B cells are not only involved primarily in antibody production against neuromuscular junction antigens, but also in antigen presentation and cytokine production, including IL1, IL6, IL10, and TNF [83-85]. Depleting or suppressing B-cell function may therefore restore immune balance. BAFF levels are also relevant, as they have been found to be increased in active disease [86].

\section{Inflammatory Myopathies}

The role of B cells is also important in diseases with a pronounced inflammatory component such as inflammatory myopathies, including polymyositis (PM) and inclusion body myositis, characterized not only by clonally expanded CD8+ cytotoxic $\mathrm{T}$ cells invading muscle fibers but also by B-cell infiltrates and plasma cells, probably connected with autoantibody production $[87,88]$. Also, BAFF transcription has been found to be significantly upregulated in both PM (14-fold) and inclusion body myositis (21-fold) compared with healthy samples [89]. In 2 other autoimmune myopathies, dermatomyositis (DM) and necrotizing autoimmune myositis, complement activation and B-cell expansions with more specific antibody production are prominent, making them more suitable myopathy subsets for anti-B-cell therapy [90]. It is therefore compelling that B-cell-depleting therapies using anti-CD20 monoclonal antibodies have been quite promising [91-95].

\section{Experience with B-Cell-Targeted Treatments in Neuroimmunological Disorders: Present and Future}

A number of drugs, monoclonal antibodies, or fusion protein, targeting the B-cell system, affecting B-cell survival, or causing B-cell depletion in a selective manner, are already being employed for autoimmune diseases and malignancies. These include drugs for chronic lymphocytic leukemia (ofatumumab, alemutuzumab, rituximab), non-Hodgkin lymphoma (rituximab), SLE (belimumab), RA resistant to disease-modifying antirheumatic drugs (rituximab, etanercept, tocilizumab), polyangiitis (rituximab), and pediatric arthritis (etanercept, tocilizumab). Concurrently, a number of clinical trials have been completed or are ongoing further evaluating these types of therapies for the treatment of autoimmune neurological disorders.

Targeting BAFF or APRIL or their receptors can affect Bcell proliferation and survival, resulting in decreased numbers of B cells in lymphoid tissue and the circulation. A drug that targets soluble BAFF is the humanized monoclonal antibody belimumab, approved for SLE (Fig. 1) [96]. This treatment affects the differentiation of B cells into antibody-producing cells and might be efficient in diseases where antibodies have a proven pathogenetic role, especially when they are being produced primarily in the periphery, for example in MG. A phase II study of belimumab in both AChR and musclespecific tyrosine kinase (MuSK)-positive MG is now in progress (NCT01480596).

Atacicept is a fusion protein that prevents BAFF and APRIL from binding to TACI and is thought to impair selectively mature B cells and plasma cells with less impact on progenitor cells and memory B cells. Though promising, this drug was tried in MS without success. A possible explanation for its inefficacy insinuates that a reduction of serum immunoglobulin caused by atacicept could disrupt nonspecific Fcreceptor blockade, which, as suggested by IVIG treatment, could have a therapeutic benefit [97]. In addition, as BLyS is believed to be involved in the differentiation of Bregs, its targeting by atacicept might tip the balance of Bregs that produce anti-inflammatory IL-10 in favor of conventional B-cells [97].

Drugs that can directly achieve B-cell depletion are directed against the CD19, CD20, and CD22 antigens that coat B cells. CD19 is a transmembrane protein physically associated with BCR, and functions to potentiate BCR signaling [98]. A humanized anti-CD19 IgG1 antibody [99], MEDI-551, is currently being trialed in MS (NCT01585766); in animal models this drug was more efficient compared than rituximab in inducing longer-lasting B-cell depletion (Fig. 1). CD22 is a member of the sialoadhesin subclass of the immunoglobulin superfamily and binds sialic acid residues. It plays a role in BCR-induced cell death and B-cell survival in the periphery [100]. Epratuzumab is a humanized IgG1 monoclonal antibody that targets CD22 but no data are yet available for neurological autoimmunity.

The most commonly used monoclonal antibodies are directed against CD20, a cell surface glycoprotein (297 amino acids, 33-37 kD) of as-yet-unknown function. CD20 is widely expressed in all stages of B-cell development except in early 


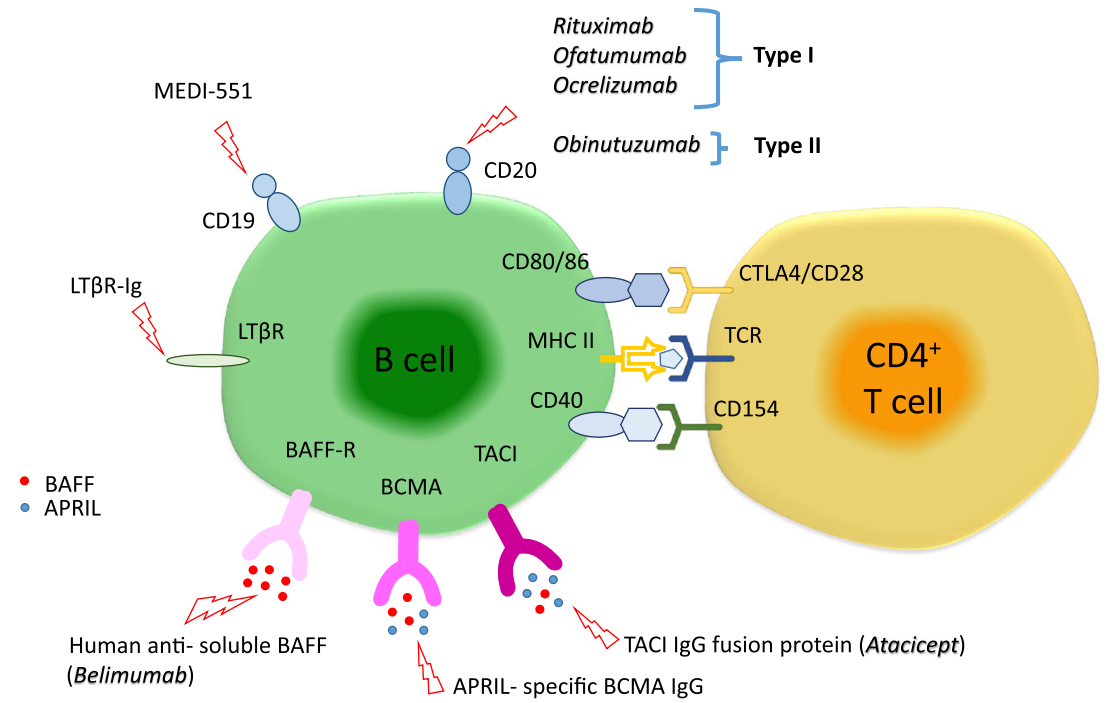

Fig. 1 Monoclonal antibodies or fusion proteins against B-cell targets. The figure highlights several B-cell molecules and their receptors, which are targeted by several different monoclonal antibodies or fusion proteins currently in the market or in clinical trials. APRIL $=$ A Proliferation Inducing Ligand; $\mathrm{BAFF}=\mathrm{B}$-cell-activating factor; $\mathrm{BAFF}-\mathrm{R}=\mathrm{B}$-cellactivating factor receptor; $\mathrm{BCMA}=\mathrm{B}$-cell-maturation antigen; CTLA4

pre-B cells and terminally differentiated plasma cells. B cells targeted via CD20 are affected by 3 main cytotoxic mechanisms; antibody-dependent cell cytotoxicity involving the $\mathrm{Fc} \gamma$ receptors $(\mathrm{Fc} \gamma \mathrm{Rs})$, complement-dependent cytotoxicity (CDC), and directly induced cellular apoptosis. Anti-CD20 monoclonal antibodies can be categorized into 2 types depending on their binding properties and mechanism of action. Type I antibodies include the most commonly used rituximab, ofatumumab, and ocrelizumab. Type II antibodies include tositumomab and obinutuzumab (Fig. 1). Type I monoclonals permit CD20 accumulation in lipid rafts, have a full CD20 binding capacity, and a high potential for inducing CDC. In contrast, type II monoclonals do not permit CD20 accumulation, have a half-maximal CD20 binding capacity (only half as many antibodies bind per B cell compared with type I), and
$=$ cytotoxic T-lymphocyte antigen $4 ; \mathrm{LT} \beta \mathrm{R}=$ lymphotoxin $-\beta$ receptor; LT $\beta$ R-Ig = antilymphotoxin $-\beta$ receptor antibody; MHC-II = major histocompatibility complex class II; TACI $=$ transmembrane activator and calcium modulator and cyclophilin ligand interactor; TCR $=$ T-cell receptor (adapted from [69])

low or no potential for CDC. Owing to a different binding topology of type I antibodies compared with type II, type I CD20 antibody complexes are swiftly internalized and degraded, resulting in reduced effector cell recruitment and antibody half-life (Fig. 2). Because type II monoclonals internalize less rapidly into target $\mathrm{B}$ cells, their action via the Fc $\gamma \mathrm{RIIb}$ is prolonged and therefore they are able to induce a much higher antibody-dependent cellular cytotoxicity as they are able to recruit monocytes, neutrophils, and dendritic cells for longer [101].

Several other anti-CD20 molecules are under development or currently in trial in the oncology field, primarily for chronic lymphocytic leukemia. These include ocaratuzumab, which is a type I, third-generation humanized Fab- and Fc-engineered IgG1 antibody with increased ability to mediate antibody-

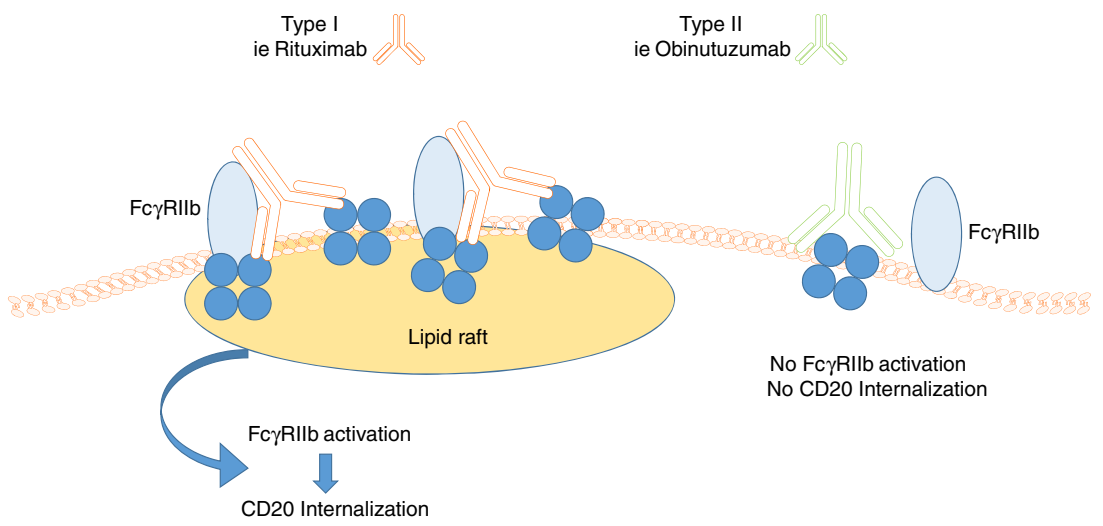

Fig. 2 Proposed model for the binding properties of type I and type II anti-CD20 monoclonal antibodies. Antibodies like rituximab (type I) may bind simultaneously to CD20 and Fc $\gamma$ RIIb, which promote internalization of CD20 in the lipid rafts. Antibodies like obinutuzumab allegedly bind solely to the CD20 tetramer, which does not lead to internalization, therefore prolonging antibody action (adapted from [101]) 
dependent cellular cytotoxicity $[102,103]$. Another available antibody is veltuzumab, also a type I antibody, which is structurally and functionally different from rituximab and has enhanced binding avidities and a stronger effect on CDC than rituximab. These drugs, among others, constitute future therapeutic options for neurological autoimmunity $[102,103]$.

Rituximab is a mouse/human chimeric anti-CD20 antibody, which effectively depletes B cells, sparing early pre-/ pro-B cells and late plasma cells. Depletion of a small subset of CD20+ T cells in patients with MS treated with rituximab has also been reported [104]. The effectiveness of rituximab therapy depends on efficient depletion of noncirculating B cells and is associated with qualitative immunological changes that indicate reconfiguration of B-cell memory through sustained reduction of autoreactive clonal expansions and Bcell repopulation characterized by the predominance of IL10producing Bregs [51, 79]. Rituximab remains detectable within the CSF after intravenous application for up to 24 weeks. Furthermore, levels of rituximab in the CSF correlate significantly with the integrity of the blood-CSF barrier [105].

Rituximab, although off-label, is a highly effective treatment of MS, especially RRMS resistant to approved regimes. An earlier open-label, phase II clinical trial of rituximab reported depletion of B cells in the CSF, which was also associated with a reduction in T cells [106]. Phase II, double-blind trials of rituximab in RRMS reported significantly reduced inflammatory brain lesions and an apparent reduction in annualized relapse rates (ARR) without any serious adverse events [107, 108]. Patients treated with rituximab had reduced total and new gadolinium-enhancing lesions for up to 48 weeks post-treatment and significantly lower number of relapses up to week 24 compared with placebo-treated patients [108].

The use of very low-dose rituximab infusions in RRMS was investigated in an open-label, proof-of-concept study. They reported that a single 100-mg infusion of rituximab adequately depletes peripheral B cells for at least 6 weeks, is well tolerated, and reduces clinical relapses [109]. Rituximab combined with mitoxantrone or as an add-on therapy in patients with relapsing MS refractory to standard injectable diseasemodifying therapies showed reduction of gadoliniumenhanced lesion numbers and of ARR [110, 111]. Moreover, long-term depression of CD19+/CD27+ memory B cells was found, associated with the prolonged effectiveness of combination therapy of rituximab and mitoxantrone [111].

A randomized, double-blind, placebo-controlled trial of rituximab treatment in patients with primary progressive MS reported that, despite a lack of significant differences in the primary end point, selective B-cell depletion may affect disease progression in younger patients, particularly those with inflammatory lesions [112].

There is currently a large amount of evidence supporting the effectiveness of rituximab in treating NMO, but no clinical trials have been conducted. Open-label studies reported a significant reduction in relapse rate and subsequent stabilization or improvement in disability as measured by expanded disability status scale scores $[63,113-117]$. Despite improving relapse rates and reducing disease activity reduced AQP4-IgG titers are not consistently associated with clinical improvement, even after long-term B-cell depletion [118]. In the largest cohort thus far, of 100 patients with NMO treated with rituximab, a $96 \%$ reduction of ARR compared with prerituximab treatment was noted [119]. This study also reported the association of the FCGR3A-F allele with the risk of relapse and insufficient memory B-cell depletion during rituximab treatment [119].

However, despite the remission rates after rituximab therapy seen in $2 / 3$ patients [120], it is clear that not all patients improve. It also remains uncertain why a number of relapses occur close to the initiation of rituximab treatment $[62,118$, $121,122]$. It has been observed that BAFF levels increase at the beginning of rituximab treatment and before the therapeutic depletion of $\mathrm{CD} 27+$ memory $\mathrm{B}$ cells takes place; this probably explains the increase in AQP4-IgG titers that is sometimes observed $[62,118,121]$. However, it is unclear whether these raises contribute to relapses because antibody titers do not correlate with disease activity $[62,118,121]$. A recent case series of patients with NMO treated with rituximab reported that 6/17 patients experienced relapses within the first week of rituximab initiation [122]. Interestingly, these patients also had relapses shortly before treatment initiation, and both preand post-treatment relapses affected the same site [122]. It is possible that the increase in proinflammatory cytokines induced soon after treatment, superimposed on a partly repaired blood-brain barrier, may lead to enhanced inflammation and disease relapse.

In contrast to the large amount of evidence for the use of rituximab for the treatment of adult patients with neurological autoimmune diseases the evidence for pediatric/juvenile cases is limited and less consistent. Still, rituximab was reported to be a highly effective treatment in an adolescent female with severe MS [123]. Two cases of pediatric patients with NMO were also treated successfully with rituximab, with good tolerability [117]. In a case series of rituximab treatment of refractory pediatric autoimmune diseases, the efficacy of rituximab was variable, ranging from complete remission to inefficacy [124]. However, Beres et al. [125] reported a case series of pediatric patients with central demyelinating disease, including RRMS, secondary progressive MS, and NMO that $82 \%$ experienced reduction of relapses after initiating rituximab without serious infusion reactions or infections.

Case reports have provided evidence that rituximab could be helpful in patients with SPS [126, 127]. Rituximab effectively treated SPS, even in cases with complications, such as dysthyroid ophthalmopathy and respiratory failure [128-130]. In a most recent report of a case study, rituximab in 
combination with tizanidine improved SPS along with the immunomodulatory effect previously caused by benzodiazepines [131]. Despite these encouraging results, rituximab failed to show increased efficacy in a controlled trial [132].

Rituximab has been tried in some patients with MG whose disease was difficult to manage with the conventional therapies. Fourteen patients with refractory generalized MG, 6 AChR-positive and 8 MuSk-positive, who did not respond to various treatments, responded, without side effects, to rituximab given at $375 \mathrm{mg} / \mathrm{m}^{2}$ every week for 1 month; sustained clinical improvement was observed in all patients, as well as a reduction of conventional immunotherapies up to $93.8 \%$ after the third cycle of rituximab treatment [133]. It is interesting that patients with $\mathrm{AChR}+$ and $\mathrm{MuSk}+\mathrm{MG}$ appear to respond differently to rituximab treatment. Although all patients show at least some improvement after rituximab treatment, this has been reported to be more long lasting and coincides with higher reduction of antibody titers, even after the cessation of rituximab treatment, chiefly in patients with MuSk + MG [133, 134]. However, a recent meta-analysis further supporting the use of rituximab in patients with refractory MG does not statistically confirm these differences and reports an overall response rate $83.9 \%$ [135]. A multi-center controlled study with rituximab in mysthenia gravis is currently ongoing.

Also encouraging is the evidence provided by case reports and open-label studies for the effectiveness of rituximab in the treatment of inflammatory myopathies, reporting response rates of up to $75 \%$ [95]. In a small open-label study of patients with DM treated with rituximab, major clinical improvement, with muscle strength increasing over baseline by $36-113 \%$, was reported. Rituximab was well tolerated, with no treatment-related severe or serious adverse events, and return of symptoms coincided with the return of B cells [94]. In another study of juvenile DM (48 patients) and adult PM (75 patients) a few indicators, including the presence of antisynthetase and anti-Mi-2 antibodies, and lower disease damage, strongly predict, as claimed by the authors, clinical improvement [91]. In a placebo-controlled study involving 200 patients, at week 8 there was no difference between the placebo group and the rituximab group, and on the basis of the study design, the results were not significant; however, at week 44, when all the patients had received rituximab, $83 \%$ met the definition of improvement [136].

The most common adverse effects of rituximab involve infusion-associated reactions, and despite their high rate they are mostly mild-to-moderate. Some clinicians advocate the use of corticosteroids and histamine antagonists prior to infusion, but our experience with large number of patients does not find this to be necessary. Overall, it is recommended to stop all antihypertensive agents at the day of infusion as rituximab can cause hypotension. Patients who experience symptomatic hypotension during the infusion respond well to an interruption of infusion for 30-60 min and restarting at a lower initial rate of not more than one-half of the previous rate. Other relatively common infusion-related reactions are influenzalike symptoms such as fever, rigors, and headache. Anaphylactic or skin reactions can occur rarely but respond well to intravenous methylprednisolone and interruption of infusion. The most severe and usually fatal adverse effect of rituximab treatment, and other lymphocyte-depleting drugs, is progressive multifocal leukoencephalopathy (PML), which is caused by the JC polyoma virus. A reduction in B-cell numbers in brain tissue may be an important contributing factor in the pathogenesis of CNS infections [137]. Although this is a very rare complication in treating neurological diseases, the seriousness of PML and its high mortality rate dictate regular monitoring of patients receiving rituximab for any new or worsening neurological symptoms or signs that might be suggestive of PML. In these rare occasions, suspension of further dosing is necessary until PML exclusion [138-140].

\section{Biomarkers of Clinical Response to B-Cell-Depletion Therapies}

Although rituximab is actively used for treating many autoimmune neurological diseases, a useful, easy-to-use biomarker of response to treatment is lacking. In many cases, treatment efficiency correlates with peripheral B-cell depletion and especially effective depletion of the $\mathrm{CD} 20+\mathrm{CD} 27+$ memory $\mathrm{B}$ cells [78]. In a small number of patients with anti-MAG neuropathy, following clinical improvement, reamplification of CD20+CD27 memory B-cell numbers appears to coincide with rising IgM levels [78]. In the same study, the patients showing no clinical improvement after rituximab were distinguished from the clinical responders by a higher load of clonal IgM memory B-cell expansions before and after therapy as well as by persistence of clonal expansions, despite efficient peripheral B-cell depletion, and by lack of substantial changes in somatic hypermutation frequencies of IgM memory B cells [79]. However, these results were based on a very small number of patients. Close monitoring of CD19+ B-cell depletion and reconstitution thereafter could provide a tool for relapse prevention and timely treatment, while further improving the benefit-risk ratio of treatment [63]. B-cell repopulation after B-cell depletion with rituximab in patients with NMO was characterized by the predominance of Bregs and restored the pretreatment disturbed balance between regulatory and memory B cells back to an advantageous state [51]. Of relevance, repeated treatment with rituximab on an individualized dosing schedule by monitoring of CD19+CD27+ memory B cells has been proposed for NMO and could have the potential to serve as a clinical tool for personalized therapy, if evaluated prospectively in a large number of patients [141].

It is therefore conceivable that monitoring Bregs pre- and post-treatment, along with memory B cells, could provide a comprehensive way of evaluating efficacious therapy in neurological autoimmune diseases, especially where cases of 
prolonged remission after rituximab treatment have been reported [142]. Also, the finding that very low doses of intrathecal rituximab may rapidly deplete peripheral blood CD19+ $\mathrm{B}$ cells (as shown in progressive MS), suggests that knowing the B-cell subtypes in different compartments may provide guidance in planning the need for follow-up treatments [143]. A proof-of-principle study reported that preamplification CD19 mRNA quantification had higher sensitivity in detecting peripheral blood CD19+ cells than flow cytometry [144], which could further improve the detection of residual CD19+ cells. Another study advocates the use of Fc $\gamma$ RIIIA polymorphisms as potential biomarkers for response to rituximab, as shown in anti-MAG neuropathy [145]. Finding more sensitive and specific biomarkers will be important in determining the frequency of infusions needed to prevent relapses or inducing long-lasting remissions, and lead to personalization of B-cell-depletion therapies.

Ocrelizumab is a recombinant humanized monoclonal antiCD20 antibody representing the humanized version of rituximab. Four clinical trials for its use in RA and 1 for its use in SLE were terminated early because at doses beneficial for the patients there was an increased incidence of serious infections [146-151]. In contrast, encouraging results have been published for its potential therapeutic effects in MS. In a phase II, randomized, placebo-controlled, multicenter trial for the treatment of RRMS, ocrelizumab was significantly superior to placebo in reducing disease activity, as measured by a decrease in gadolinium-enhancing magnetic resonance imaging lesions, and reduction of ARR without significant serious adverse effects, serious infections, or the development of antihuman antibodies [152]. With great attention to safety, 4 phase II/III clinical trials of ocrelizumab in RRMS and primary progressive MS are underway (NCT01412333, NCT01194570, NCT00676715, NCT01765361).

Ofatumumab (Arzerra; Novartis Oncology, Basel, Switzerland) is a fully humanized anti-CD20 monoclonal antibody that also targets CD20. It targets different CD20 epitopes compared to rituximab, binding not only the large loop of CD20, but also the small loop closer to the B-cell membrane. As a result, B-cell lysis is more effective. In a randomized, doubleblind, placebo-controlled phase II clinical trial of ofatumumab in RRMS, ofatumumab treatment was associated with profound selective reduction of CD19+ B cells, and suppression of both $\mathrm{T} 1$ and $\mathrm{T} 2$ magnetic resonance imaging lesions, but no significant changes in expanded disability status scale scores, multiple sclerosis functional composite (MSFC) scores, and no not increase the number of serious adverse events were reported [153]. In 2 reported cases, 1 of which was pediatric opsoclonus-myoclonus syndrome, ofatumumab was well tolerated, resulting in neurological improvement for at least 6 months with concurrent reduction of autoantibodies titers and elimination of CSF B-cell expansion [154, 155]. Another randomized, double-blind, placebo-controlled phase II study investigating the safety and efficacy of a subcutaneous formulation of ofatumumab in the treatment of RRMS was completed in June 2015 and the results are pending (NCT01457924).

Obinutuzumab (GAZYVA; Genentech, San Francisco, CA, USA) is a CD20-directed cytolytic antibody approved in combination with chlorambucil for the treatment of patients with previously untreated chronic lymphocytic leukemia. It is a type II antibody and, as previously discussed, has increased efficiency in B-cell depletion in chronic lymphocytic leukemia compared with type I anti-CD20 antibodies. Future use in autoimmune neurological conditions should include MS and NMO in which rituximab, a type I antibody, has already been used with good results.

\section{The New Era of Biological Therapeutics}

Novel therapies that specifically target elements of the immune system, B cells, T cells, and various receptors have revolutionized the field of immunotherapies, constituting a paradigm shift from previous generation therapies that suppressed or modulated the immune system indiscriminately. These specific therapies, often developed for hematological malignancies, have found their niche in the effective management of difficult neurological diseases. As new data emerge, almost on a daily basis, regarding the pathophysiology of autoimmune neurological diseases, clinicians are becoming more and more able to select the most appropriate therapy for treating a specific disease. Innovative research in the field of neurotherapeutics not only aims to develop more potent drugs, that is, drugs that eliminate more efficiently a particular cell population or are better tolerated and safer, but also aims at identifying specific biomarkers informative for selecting and monitoring the most appropriate therapy. In the field of B-cell therapies future research will focus on drugs that may also target plasma cells or drugs that may not affect Bregs. How these indices correlate to clinical improvement on a single-patient basis will be very useful for tailor-made therapies. The exciting news with current experience is that in many cases where anti-B-cell therapy is effective, the improvement seems long-lasting like that seen in MuSKpositive MG.

Required Author Forms Disclosure forms provided by the authors are available with the online version of this article.

\section{References}

1. Eibel H, Kraus H, Sic H, Kienzler AK, Rizzi M. B cell biology: an overview. Curr Allergy Asthma Rep 2014;14:434.

2. Pieper K, Grimbacher B, Eibel H. B-cell biology and development. J Allergy Clin Immunol 2013;131:959-971. 
3. Weinstein E, Peeva E, Putterman C, Diamond B. B-cell biology. Rheum Dis Clin North Am 2004;30:159-174.

4. Kitano M, Moriyama S, Ando Y, et al. Bcl6 protein expression shapes pre-germinal center $\mathrm{B}$ cell dynamics and follicular helper $\mathrm{T}$ cell heterogeneity. Immunity 2011;34:961-972.

5. O'Connor BP, Vogel LA, Zhang W, et al. Imprinting the fate of antigen-reactive $\mathrm{B}$ cells through the affinity of the B cell receptor. J Immunol 2006;177:7723-7732.

6. Kurosaki T, Kometani K, Ise W. Memory B cells. Nat Rev Immunol 2015;15:149-159.

7. Nutt SL, Hodgkin PD, Tarlinton DM, Corcoran LM. The generation of antibody-secreting plasma cells. Nat Rev Immunol 2015;15:160-171.

8. Anolik JH, Barnard J, Owen T, et al. Delayed memory B cell recovery in peripheral blood and lymphoid tissue in systemic lupus erythematosus after B cell depletion therapy. Arthritis Rheum 2007:56:3044-3056

9. Dass S, Rawstron AC, Vital EM, Henshaw K, McGonagle D, Emery P. Highly sensitive B cell analysis predicts response to rituximab therapy in rheumatoid arthritis. Arthritis Rheum 2008;58:2993-2999.

10. Palanichamy A, Barnard J, Zheng B, et al. Novel human transitional B cell populations revealed by B cell depletion therapy. J Immunol 2009;182:5982-5993.

11. Roll P, Dorner T, Tony HP. Anti-CD20 therapy in patients with rheumatoid arthritis: predictors of response and B cell subset regeneration after repeated treatment. Arthritis Rheum 2008;58: 1566-1575.

12. Adlowitz DG, Barnard J, Biear JN, et al. Expansion of activated peripheral blood memory B cells in rheumatoid arthritis, impact of $\mathrm{B}$ cell depletion therapy, and biomarkers of response. PLoS One 2015;10:e0128269.

13. Moore PA, Belvedere O, Orr A, et al. BLyS: member of the tumor necrosis factor family and B lymphocyte stimulator. Science 1999;285:260-263.

14. Schneider P, MacKay F, Steiner V, et al. BAFF, a novel ligand of the tumor necrosis factor family, stimulates B cell growth. J Exp Med 1999;189:1747-1756.

15. Hahne M, Kataoka T, Schroter M, et al. APRIL, a new ligand of the tumor necrosis factor family, stimulates tumor cell growth. J Exp Med 1998;188:1185-1190.

16. Cachero TG, Schwartz IM, Qian F, et al. Formation of virus-like clusters is an intrinsic property of the tumor necrosis factor family member BAFF (B cell activating factor). Biochemistry 2006;45: 2006-2013.

17. Liu Y, Xu L, Opalka N, Kappler J, Shu HB, Zhang G. Crystal structure of sTALL-1 reveals a virus-like assembly of TNF family ligands. Cell 2002;108:383-394.

18. Lopez-Fraga M, Fernandez R, Albar JP, Hahne M. Biologically active APRIL is secreted following intracellular processing in the Golgi apparatus by furin convertase. EMBO Rep 2001;2:945-951.

19. Lavie F, Miceli-Richard C, Ittah M, Sellam J, Gottenberg JE, Mariette X. B-cell activating factor of the tumour necrosis factor family expression in blood monocytes and $\mathrm{T}$ cells from patients with primary Sjogren's syndrome. Scand J Immunol 2008;67:185192

20. Moreaux J, Legouffe E, Jourdan E, et al. BAFF and APRIL protect myeloma cells from apoptosis induced by interleukin 6 deprivation and dexamethasone. Blood 2004;103:3148-3157.

21. Suzuki K, Setoyama Y, Yoshimoto K, Tsuzaka K, Abe T, Takeuchi T. Effect of interleukin-2 on synthesis of B cell activating factor belonging to the tumor necrosis factor family (BAFF) in human peripheral blood mononuclear cells. Cytokine 2008;44:44-48.

22. Bossen C, Cachero TG, Tardivel A, et al. TACI, unlike BAFF-R, is solely activated by oligomeric BAFF and APRIL to support survival of activated B cells and plasmablasts. Blood 2008;111: 1004-1012.

23. Day ES, Cachero TG, Qian F, et al. Selectivity of BAFF/BLyS and APRIL for binding to the TNF family receptors BAFFR/BR3 and BCMA. Biochemistry 2005;44:1919-1931.

24. Zhang L, Zheng S, Wu H, et al. Identification of BLyS (B lymphocyte stimulator), a non-myelin-associated protein, as a functional ligand for Nogo-66 receptor. J Neurosci 2009;29:63486352

25. Ingold K, Zumsteg A, Tardivel A, et al. Identification of proteoglycans as the APRIL-specific binding partners. J Exp Med 2005;201:1375-1383.

26. Mihalcik SA, Huddleston PM, 3rd, Wu X, Jelinek DF. The structure of the TNFRSF13C promoter enables differential expression of BAFF-R during B cell ontogeny and terminal differentiation. J Immunol 2010;185:1045-1054.

27. Yan M, Brady JR, Chan B, et al. Identification of a novel receptor for B lymphocyte stimulator that is mutated in a mouse strain with severe B cell deficiency. Curr Biol 2001;11:1547-1552.

28. Lougaris V, Gallizzi R, Vitali M, et al. A novel compound heterozygous TACI mutation in an autosomal recessive common variable immunodeficiency (CVID) family. Hum Immunol 2012;73: 836-839.

29. Martinez-Gallo M, Radigan L, Almejun MB, Martinez-Pomar N, Matamoros N, Cunningham-Rundles C. TACI mutations and impaired B-cell function in subjects with CVID and healthy heterozygotes. J Allergy Clin Immunol 2013;131:468-476.

30. O'Connor BP, Raman VS, Erickson LD, et al. BCMA is essential for the survival of long-lived bone marrow plasma cells. J Exp Med 2004;199:91-98.

31. Rosser EC, Mauri C. Regulatory B cells: origin, phenotype, and function. Immunity 2015;42:607-612

32. van de Veen $\mathrm{W}$, Stanic B, Yaman G, et al. IgG4 production is confined to human IL-10-producing regulatory B cells that suppress antigen-specific immune responses. J Allergy Clin Immunol 2013;131:1204-1212.

33. Mauri $\mathrm{C}$, Menon M. The expanding family of regulatory B cells Int Immunol 2015;27:479-486.

34. Duddy M, Niino M, Adatia F, et al. Distinct effector cytokine profiles of memory and naive human B cell subsets and implication in multiple sclerosis. J Immunol 2007;178:6092-6099.

35. Shen P, Roch T, Lampropoulou V, et al. IL-35-producing B cells are critical regulators of immunity during autoimmune and infectious diseases. Nature 2014;507:366-370.

36. Iwata $\mathrm{Y}$, Matsushita T, Horikawa $\mathrm{M}$, et al. Characterization of a rare IL-10-competent B-cell subset in humans that parallels mouse regulatory B10 cells. Blood 2011;117:530-541.

37. Miyagaki T, Fujimoto M, Sato S. Regulatory B cells in human inflammatory and autoimmune diseases: from mouse models to clinical research. Int Immunol 2015;27:495-504.

38. Tussiwand R, Bosco N, Ceredig R, Rolink AG. Tolerance checkpoints in B-cell development: Johnny B good. Eur J Immunol 2009;39:2317-2324

39. Dalakas MC. B cells as therapeutic targets in autoimmune neurological disorders. Nat Clin Pract Neurol 2008;4:557-567.

40. Frischer JM, Bramow S, Dal-Bianco A, et al. The relation between inflammation and neurodegeneration in multiple sclerosis brains. Brain 2009;132:1175-1189.

41. Ozawa K, Suchanek G, Breitschopf H, et al. Patterns of oligodendroglia pathology in multiple sclerosis. Brain 1994;117:13111322.

42. Dendrou CA, Fugger L, Friese MA. Immunopathology of multiple sclerosis. Nat Rev Immunol 2015;15:545-558.

43. Corcione A, Casazza S, Ferretti E, et al. Recapitulation of B cell differentiation in the central nervous system of patients with multiple sclerosis. Proc Natl Acad Sci U S A 2004;101:11064-11069. 
44. Harp CT, Ireland S, Davis LS, et al. Memory B cells from a subset of treatment-naive relapsing-remitting multiple sclerosis patients elicit CD4(+) T-cell proliferation and IFN-gamma production in response to myelin basic protein and myelin oligodendrocyte glycoprotein. Eur J Immunol 2010;40:2942-2956.

45. Niino M, Hirotani M, Miyazaki Y, Sasaki H. Memory and naive B-cell subsets in patients with multiple sclerosis. Neurosci Lett 2009;464:74-78.

46. Habib J, Deng J, Lava N, Tyor W, Galipeau J. Blood B cell and regulatory subset content in multiple sclerosis patients. J Mult Scler (Foster City) 2015;2.

47. Knippenberg S, Peelen E, Smolders J, et al. Reduction in IL-10 producing $\mathrm{B}$ cells (Breg) in multiple sclerosis is accompanied by a reduced naive/memory Breg ratio during a relapse but not in remission. J Neuroimmunol 2011;239:80-86.

48. Michel L, Chesneau M, Manceau P, et al. Unaltered regulatory Bcell frequency and function in patients with multiple sclerosis. Clin Immunol 2014;155:198-208.

49. Quan C, Yu H, Qiao J, et al. Impaired regulatory function and enhanced intrathecal activation of B cells in neuromyelitis optica: distinct from multiple sclerosis. Mult Scler 2013;19:289-298.

50. Hirotani M, Niino M, Fukazawa T, et al. Decreased IL-10 production mediated by Toll-like receptor 9 in B cells in multiple sclerosis. J Neuroimmunol 2010;221:95-100.

51. Quan C, ZhangBao J, Lu J, et al. The immune balance between memory and regulatory B cells in NMO and the changes of the balance after methylprednisolone or rituximab therapy. J Neuroimmunol 2015;282:45-53.

52. Myers KJ, Sprent J, Dougherty JP, Ron Y. Synergy between encephalitogenic T cells and myelin basic protein-specific antibodies in the induction of experimental autoimmune encephalomyelitis. J Neuroimmunol 1992;41:1-8.

53. Willenborg DO, Prowse SJ. Immunoglobulin-deficient rats fail to develop experimental allergic encephalomyelitis. J Neuroimmunol 1983;5:99-109.

54. Matsushita T, Horikawa M, Iwata Y, Tedder TF. Regulatory B cells (B10 cells) and regulatory T cells have independent roles in controlling experimental autoimmune encephalomyelitis initiation and late-phase immunopathogenesis. J Immunol 2010;185:22402252.

55. Brilot F, Dale RC, Selter RC, et al. Antibodies to native myelin oligodendrocyte glycoprotein in children with inflammatory demyelinating central nervous system disease. Ann Neurol 2009;66: 833-842.

56. Chalmoukou K, Alexopoulos H, Akrivou S, Stathopoulos P, Reindl M, Dalakas MC. Anti-MOG antibodies are frequently associated with steroid-sensitive recurrent optic neuritis. Neurol Neuroimmunol Neuroinflamm 2015;2:e131.

57. Waters P, Woodhall M, O'Connor KC, et al. MOG cell-based assay detects non-MS patients with inflammatory neurologic disease. Neurol Neuroimmunol Neuroinflamm 2015;2:e89.

58. Wang H, Wang K, Zhong X, et al. Cerebrospinal fluid BAFF and APRIL levels in neuromyelitis optica and multiple sclerosis patients during relapse. J Clin Immunol 2012;32:1007-1011.

59. Krumbholz M, Faber H, Steinmeyer F, et al. Interferon-beta increases BAFF levels in multiple sclerosis: implications for B cell autoimmunity. Brain 2008;131:1455-1463.

60. Krumbholz M, Theil D, Derfuss T, et al. BAFF is produced by astrocytes and up-regulated in multiple sclerosis lesions and primary central nervous system lymphoma. J Exp Med 2005;201: 195-200.

61. Kim SH, Kim W, Li XF, Jung IJ, Kim HJ. Repeated treatment with rituximab based on the assessment of peripheral circulating memory B cells in patients with relapsing neuromyelitis optica over 2 years. Arch Neurol 2011;68:1412-1420.
62. Pellkofer HL, Krumbholz M, Berthele A, et al. Long-term followup of patients with neuromyelitis optica after repeated therapy with rituximab. Neurol 2011;76:1310-1315.

63. Radaelli M, Moiola L, Sangalli F, et al. Neuromyelitis optica spectrum disorders: long-term safety and efficacy of rituximab in Caucasian patients. Mult Scler 2015.

64. Satoh J, Onoue H, Arima K, Yamamura T. Nogo-A and nogo receptor expression in demyelinating lesions of multiple sclerosis. J Neuropathol Exp Neurol 2005;64:129-138.

65. Dalakas MC. Autoimmune peripheral neuropathies. In: Rich RR, Fleisher TA, Shearer WT (eds.). Clinical immunology: principles and practice. Philadelphia, PA: Mosby Elsevier, 2011, pp. 977994.

66. Kusunoki S, Kaida K. Antibodies against ganglioside complexes in Guillain-Barre syndrome and related disorders. J Neurochem 2011;116:828-832.

67. Willison HJ, Yuki N. Peripheral neuropathies and anti-glycolipid antibodies. Brain 2002;125:2591-2625.

68. Yuki N, Hartung HP. Guillain-Barré syndrome. N Engl J Med 2012;366:2294-2304.

69. Dalakas MC. Advances in the diagnosis, pathogenesis and treatment of CIDP. Nat Rev Neurol 2011;7:507-517.

70. Dalakas MC, Engel WK. Immunoglobulin and complement deposits in nerves of patients with chronic relapsing polyneuropathy. Arch Neurol 1980;37:637-640.

71. Dalakas MC, Houff SA, Engel WK, Madden DL, Sever JL. CSF "monoclonal" bands in chronic relapsing polyneuropathy. Neurology 1980;30:864-867.

72. Stathopoulos P, Alexopoulos H, Dalakas MC. Autoimmune antigenic targets at the node of Ranvier in demyelinating disorders. Nat Rev Neurol 2015;11:143-156.

73. Tackenberg B, Jelcic I, Baerenwaldt A, et al. Impaired inhibitory $\mathrm{Fc} \gamma$ receptor IIB expression on B cells in chronic inflammatory demyelinating polyneuropathy. Proc Natl Acad Sci U S A 2009; 106:4788-4792.

74. Ritter C, Forster D, Albrecht P, Hartung HP, Kieseier BC, Lehmann HC. IVIG regulates BAFF expression in patients with chronic inflammatory demyelinating polyneuropathy (CIDP). J Neuroimmunol 2014;274:225-229.

75. Monaco S, Bonetti B, Ferrari S, et al. Complement-mediated demyelination in patients with IgM monoclonal gammopathy and polyneuropathy. N Engl J Med 1990;322:649-652.

76. Lombardi R, Erne B, Lauria G, et al. IgM deposits on skin nerves in anti-myelin-associated glycoprotein neuropathy. Ann Neurol 2005;57:180-187.

77. Campagnolo M, Ferrari S, Dalla Torre C, et al. Polyneuropathy with anti-sulfatide and anti-MAG antibodies: clinical, neurophysiological, pathological features and response to treatment. J Neuroimmunol 2015;281:1-4.

78. Dalakas MC, Rakocevic G, Salajegheh M, et al. Placebocontrolled trial of rituximab in IgM anti-myelin-associated glycoprotein antibody demyelinating neuropathy. Ann Neurol 2009;65: 286-293.

79. Maurer MA, Rakocevic G, Leung CS, et al. Rituximab induces sustained reduction of pathogenic B cells in patients with peripheral nervous system autoimmunity. J Clin Invest 2012;122:13931402.

80. Rizzi M, Knoth R, Hampe CS, et al. Long-lived plasma cells and memory B cells produce pathogenic anti-GAD65 autoantibodies in Stiff Person Syndrome. PLoS One 2010;5:e10838.

81. Dalakas MC, Li M, Fujii M, Jacobowitz DM. Stiff person syndrome: quantification, specificity, and intrathecal synthesis of GAD65 antibodies. Neurology 2001;57:780-784.

82. Geis C, Weishaupt A, Hallermann S, et al. Stiff person syndromeassociated autoantibodies to amphiphysin mediate reduced GABAergic inhibition. Brain 2010;133:3166-3180. 
83. Cohen-Kaminsky S, Delattre RM, Devergne O, et al. High IL-6 gene expression and production by cultured human thymic epithelial cells from patients with myasthenia gravis. Ann N Y Acad Sci 1993;681:97-99.

84. Huang D, Pirskanen R, Hjelmstrom P, Lefvert AK. Polymorphisms in IL-1beta and IL-1 receptor antagonist genes are associated with myasthenia gravis. J Neuroimmunol 1998;81: 76-81.

85. Huang YM, Kivisakk P, Ozenci V, Pirskanen R, Link H. Increased levels of circulating acetylcholine receptor (AChR)-reactive IL10 -secreting cells are characteristic for myasthenia gravis (MG). Clin Exp Immunol 1999;118:304-308.

86. Ragheb S, Lisak R, Lewis R, Van Stavern G, Gonzales F, Simon $\mathrm{K}$. A potential role for B-cell activating factor in the pathogenesis of autoimmune myasthenia gravis. Arch Neurol 2008;65:13581362.

87. Dalakas MC. Inflammatory myopathies: management of steroid resistance. Curr Opin Neurol 2011;24:457-462.

88. Greenberg SA, Pinkus GS, Amato AA, Pinkus JL. Myeloid dendritic cells in inclusion-body myositis and polymyositis. Muscle Nerve 2007;35:17-23.

89. Salajegheh M, Kong SW, Pinkus JL, et al. Interferon-stimulated gene 15 (ISG15) conjugates proteins in dermatomyositis muscle with perifascicular atrophy. Ann Neurol 2010;67:53-63.

90. Dalakas MC. Inflammatory muscle diseases. N Engl J Med 2015;373:393-394.

91. Aggarwal R, Bandos A, Reed AM, et al. Predictors of clinical improvement in rituximab-treated refractory adult and juvenile dermatomyositis and adult polymyositis. Arthritis Rheumatol 2014;66:740-749.

92. Chung L, Genovese MC, Fiorentino DF. A pilot trial of rituximab in the treatment of patients with dermatomyositis. Arch Dermatol 2007;143:763-767.

93. Haroon M, Devlin J. Rituximab as a first-line agent for the treatment of dermatomyositis. Rheumatol Int 2012;32:1783-1784.

94. Levine TD. Rituximab in the treatment of dermatomyositis: an open-label pilot study. Arthritis Rheum 2005;52:601-607.

95. Rios Fernandez R, Callejas Rubio JL, Sanchez Cano D, Saez Moreno JA, Ortego Centeno N. Rituximab in the treatment of dermatomyositis and other inflammatory myopathies. A report of 4 cases and review of the literature. Clin Exp Rheumatol 2009;27:1009-1016.

96. Leone A, Sciascia S, Kamal A, Khamashta M. Biologicals for the treatment of systemic lupus erythematosus: current status and emerging therapies. Exp Rev Clin Immunol 2015;11:109-116.

97. Luhder F, Gold R. Trial and error in clinical studies: lessons from ATAMS. Lancet Neurol 2014;13:340-341.

98. Fujimoto M, Poe JC, Hasegawa M, Tedder TF. CD19 regulates intrinsic B lymphocyte signal transduction and activation through a novel mechanism of processive amplification. Immunol Res 2000;22:281-298.

99. Herbst R, Wang Y, Gallagher S, et al. B-cell depletion in vitro and in vivo with an afucosylated anti-CD19 antibody. J Pharmacol Exp Ther 2010;335:213-222.

100. Tedder TF, Poe JC, Haas KM. CD22: a multifunctional receptor that regulates B lymphocyte survival and signal transduction. Adv Immunol 2005;88:1-50.

101. Goede V, Klein C, Stilgenbauer S. Obinutuzumab (GA101) for the treatment of chronic lymphocytic leukemia and other B-cell nonhodgkin's lymphomas: a glycoengineered type II CD20 antibody. Oncol Res Treat 2015;38:185-192.

102. Robak P, Smolewski P, Robak T. Emerging immunological drugs for chronic lymphocytic leukemia. Exp Opin Emerg Drugs 2015;20:423-447.

103. Teo EC, Chew Y, Phipps C. A review of monoclonal antibody therapies in lymphoma. Crit Rev Oncol Hematol 2015.
104. Palanichamy A, Jahn S, Nickles D, et al. Rituximab efficiently depletes increased CD20-expressing T cells in multiple sclerosis patients. J Immunol 2014;193:580-586.

105. Petereit HF, Rubbert-Roth A. Rituximab levels in cerebrospinal fluid of patients with neurological autoimmune disorders. Mult Scler 2009;15:189-192.

106. Cross AH, Stark JL, Lauber J, Ramsbottom MJ, Lyons JA. Rituximab reduces B cells and T cells in cerebrospinal fluid of multiple sclerosis patients. J Neuroimmunol 2006;180:63-70.

107. Bar-Or A, Calabresi PA, Arnold D, et al. Rituximab in relapsingremitting multiple sclerosis: a 72-week, open-label, phase I trial. Ann Neurol 2008;63:395-400

108. Hauser SL, Waubant E, Arnold DL, et al. B-cell depletion with rituximab in relapsing-remitting multiple sclerosis. N Engl J Med 2008;358:676-688.

109. Nielsen AS, Miravalle A, Langer-Gould A, Cooper J, Edwards KR, Kinkel RP. Maximally tolerated versus minimally effective dose: the case of rituximab in multiple sclerosis. Mult Scler 2012;18:377-378.

110. Cross AH, Klein RS, Piccio L. Rituximab combination therapy in relapsing multiple sclerosis. Ther Adv Neurol Disord 2012;5:311319.

111. Evdoshenko E, Maslyanskiy A, Lapin S, et al. Dynamics of B-cell populations in CSF and blood in patients treated with a combination of rituximab and mitoxantrone. ISRN Neurol 2013;2013: 748127.

112. Hawker K, O'Connor P, Freedman MS, et al. Rituximab in patients with primary progressive multiple sclerosis: results of a randomized double-blind placebo-controlled multicenter trial. Ann Neurol 2009;66:460-471.

113. Bedi GS, Brown AD, Delgado SR, Usmani N, Lam BL, Sheremata WA. Impact of rituximab on relapse rate and disability in neuromyelitis optica. Mult Scler 2011;17:1225-1230.

114. Cree BA, Lamb S, Morgan K, Chen A, Waubant E, Genain C. An open label study of the effects of rituximab in neuromyelitis optica. Neurology 2005;64:1270-1272.

115. Ip VH, Lau AY, Au LW, et al. Rituximab reduces attacks in Chinese patients with neuromyelitis optica spectrum disorders. J Neurol Sci 2013;324:38-39.

116. Jacob A, Weinshenker BG, Violich I, et al. Treatment of neuromyelitis optica with rituximab: retrospective analysis of 25 patients. Arch Neurol 2008;65:1443-1448.

117. Mahmood NA, Silver K, Onel K, Ko M, Javed A. Efficacy and safety of rituximab in pediatric neuromyelitis optica. J Child Neurol 2011;26:244-247.

118. Gredler V, Mader S, Schanda K, et al. Clinical and immunological follow-up of B-cell depleting therapy in CNS demyelinating diseases. J Neurol Sci 2013;328:77-82.

119. Kim SH, Jeong IH, Hyun JW, et al. Treatment outcomes with rituximab in 100 patients with neuromyelitis optica: influence of FCGR3A polymorphisms on the therapeutic response to rituximab. JAMA Neurol 2015;72:989-995.

120. Mealy MA, Wingerchuk DM, Palace J, Greenberg BM, Levy M. Comparison of relapse and treatment failure rates among patients with neuromyelitis optica: multicenter study of treatment efficacy. JAMA Neurol 2014;71:324-330.

121. Nakashima I, Takahashi T, Cree BA, et al. Transient increases in anti-aquaporin-4 antibody titers following rituximab treatment in neuromyelitis optica, in association with elevated serum BAFF levels. J Clin Neurosci 2011;18:997-998.

122. Perumal JS, Kister I, Howard J, Herbert J. Disease exacerbation after rituximab induction in neuromyelitis optica. Neurol Neuroimmunol Neuroinflamm 2015;2:e61.

123. Karenfort M, Kieseier BC, Tibussek D, Assmann B, Schaper J, Mayatepek E. Rituximab as a highly effective treatment in a 
female adolescent with severe multiple sclerosis. Develop Med Child Neurol 2009;51:159-161.

124. Tzaribachev N, Koetter I, Kuemmerle-Deschner JB, Schedel J. Rituximab for the treatment of refractory pediatric autoimmune diseases: a case series. Cases J 2009;2:6609

125. Beres SJ, Graves J, Waubant E. Rituximab use in pediatric central demyelinating disease. Pediatr Neurol 2014;51:114-118.

126. Bacorro EA, Tehrani R. Stiff-person syndrome: persistent elevation of glutamic acid decarboxylase antibodies despite successful treatment with rituximab. J Clin Rheumatol 2010;16:237-239.

127. Lobo ME, Araujo ML, Tomaz CA, Allam N. Stiff-person syndrome treated with rituximab. BMJ Case Rep 2010;2010.

128. Dupond JL, Essalmi L, Gil H, Meaux-Ruault N, Hafsaoui C. Rituximab treatment of stiff-person syndrome in a patient with thymoma, diabetes mellitus and autoimmune thyroiditis. J Clin Neurosci 2010;17:389-391.

129. Katoh N, Matsuda M, Ishii W, Morita H, Ikeda S. Successful treatment with rituximab in a patient with stiff-person syndrome complicated by dysthyroid ophthalmopathy. Intern Med 2010;49: 237-241.

130. Qureshi A, Hennessy M. Stiff person syndrome (SPS) complicated by respiratory failure: successful treatment with rituximab. J Neurol 2012;259:180-181.

131. Zdziarski P. A case of stiff person syndrome: immunomodulatory effect of benzodiazepines: successful rituximab and tizanidine therapy. Medicine 2015;94:e954.

132. Dalakas MC, Rakocevic G, Dambrosia J, McElroy B. A doubleblind, placebo-cotrolled study of rituximab in patients with stiffperson syndrome (SPS). Ann Neurol 2009;66:S20.

133. Nowak RJ, Dicapua DB, Zebardast N, Goldstein JM. Response of patients with refractory myasthenia gravis to rituximab: a retrospective study. Ther Adv Neurol Disord 2011;4:259-266.

134. Keung B, Robeson KR, DiCapua DB, et al. Long-term benefit of rituximab in MuSK autoantibody myasthenia gravis patients. $\mathrm{J}$ Neurol Neurosurg Psychiatry 2013;84:1407-1409.

135. Iorio R, Damato V, Alboini PE, Evoli A. Efficacy and safety of rituximab for myasthenia gravis: a systematic review and metaanalysis. J Neurol 2015;262:1115-1119.

136. Oddis CV, Reed AM, Aggarwal R, et al. Rituximab in the treatment of refractory adult and juvenile dermatomyositis and adult polymyositis: a randomized, placebo-phase trial. Arthritis Rheum 2013;65:314-324.

137. Martin Mdel P, Cravens PD, Winger R, et al. Depletion of B lymphocytes from cerebral perivascular spaces by rituximab. Arch Neurol 2009;66:1016-1020.

138. Carson KR, Focosi D, Major EO, et al. Monoclonal antibodyassociated progressive multifocal leucoencephalopathy in patients treated with rituximab, natalizumab, and efalizumab: a Review from the Research on Adverse Drug Events and Reports (RADAR) Project. Lancet Oncol 2009;10:816-824.

139. De Palma R, Sementa A. Rituximab in relapsing-remitting multiple sclerosis. N Engl J Med 2008;358:2645-2646.

140. Shetty S, Ahmed AR. Preliminary analysis of mortality associated with rituximab use in autoimmune diseases. Autoimmunity 2013;46:487-496.

141. Kim SH, Huh SY, Lee SJ, Joung A, Kim HJ. A 5-year follow-up of rituximab treatment in patients with neuromyelitis optica spectrum disorder. JAMA Neurol 2013;70:1110-1117.
142. Weinfurtner K, Graves J, Ness J, Krupp L, Milazzo M, Waubant E. Prolonged remission in neuromyelitis optica following cessation of rituximab treatment. J Child Neurol 2015;30:1366-1370.

143. Svenningsson A, Bergman J, Dring A, et al. Rapid depletion of B lymphocytes by ultra-low-dose rituximab delivered intrathecally. Neurol Neuroimmunol Neuroinflamm 2015;2:e79.

144. Marnetto F, Granieri L, Valentino P, Capobianco M, Pautasso M, Bertolotto A. CD19 mRNA quantification improves rituximab treatment-to-target approach: a proof of concept study. J Neuroimmunol 2014;277:127-133.

145. Stork AC, Notermans NC, van den Berg LH, et al. Fcgamma receptor IIIA genotype is associated with rituximab response in antimyelin-associated glycoprotein neuropathy. J Neurol Neurosurg Psychiatry 2014;85:918-920.

146. Emery P, Rigby W, Tak PP, et al. Safety with ocrelizumab in rheumatoid arthritis: results from the ocrelizumab phase III program. PLoS One 2014;9:e87379.

147. Harigai M, Tanaka Y, Maisawa S. Safety and efficacy of various dosages of ocrelizumab in Japanese patients with rheumatoid arthritis with an inadequate response to methotrexate therapy: a placebo-controlled double-blind parallel-group study. J Rheumatol 2012;39:486-495.

148. Mysler EF, Spindler AJ, Guzman R, et al. Efficacy and safety of ocrelizumab in active proliferative lupus nephritis: results from a randomized, double-blind, phase III study. Arthritis Rheum 2013;65:2368-2379.

149. Rigby W, Tony HP, Oelke K, et al. Safety and efficacy of ocrelizumab in patients with rheumatoid arthritis and an inadequate response to methotrexate: results of a forty-eight-week randomized, double-blind, placebo-controlled, parallel-group phase III trial. Arthritis Rheum 2012;64:350-359.

150. Stohl W, Gomez-Reino J, Olech E, et al. Safety and efficacy of ocrelizumab in combination with methotrexate in MTX-naive subjects with rheumatoid arthritis: the phase III FILM trial. Ann Rheum Dis 2012;71:1289-1296.

151. Tak PP, Mease PJ, Genovese MC, et al. Safety and efficacy of ocrelizumab in patients with rheumatoid arthritis and an inadequate response to at least one tumor necrosis factor inhibitor: results of a forty-eight-week randomized, double-blind, placebocontrolled, parallel-group phase III trial. Arthritis Rheum 2012;64:360-370.

152. Kappos L, Li D, Calabresi PA, et al. Ocrelizumab in relapsingremitting multiple sclerosis: a phase 2 , randomised, placebo-controlled, multicentre trial. Lancet 2011;378:1779-1787.

153. Sorensen PS, Lisby S, Grove R, et al. Safety and efficacy of ofatumumab in relapsing-remitting multiple sclerosis: a phase 2 study. Neurology 2014;82:573-581.

154. Ketterl TG, Messinger YH, Niess DR, Gilles E, Engel WK, Perkins JL. Ofatumumab for refractory opsoclonus-myoclonus syndrome following treatment of neuroblastoma. Pediatr Blood Cancer 2013;60:E163-E165.

155. Pranzatelli MR, Tate ED, Shenoy S, Travelstead AL. Ofatumumab for a rituximab-allergic child with chronic-relapsing paraneoplastic opsoclonus-myoclonus. Pediatr Blood Cancer 2012;58:988-991. 